\title{
Manggarai Folklore: Challenges of Transmission and Preservation in the Digital Era
}

\author{
Ans Prawati Yuliantari \\ \{tia.yuliantari@gmail.com\}
}

UNIKA Katolik Indonesia Santu Paulus Ruteng, Indonesia

\begin{abstract}
This article aims to discuss the understanding of Manggarai youth of their folklore and the methods of transmission between generations. A qualitative research design was used with survey and interview methods to obtain data. The survey was conducted on 146 students and in-depth interviews took 15 people who were considered to be representative of all respondents. Based on the analysis, it can be seen that the inheritance of Manggarai folktales still occurs, although the number of known folktales is insignificant compared to the number of Manggarai folktales that have been transliterated and known by the Manggarai community. In addition, based on the level of education and the language used for intergenerational inheritance, it shows the reduced role of the Manggarai language, and a new transmission method is needed by the dynamics of the community so that the preservation of folklore can be carried out in the future.
\end{abstract}

Keywords: folklore; transmission; preservation; manggarai

\section{Introduction}

Folklore is a cultural treasure that contains elements of the philosophy, values, and customs of a community. Therefore, its preservation becomes an important issue when modernity and globalization make cultural elements mixed up and easily accessible to everyone. Folklore is a picture of ethnicity from various angles as said by Willian A.Wilson [1] "If we speak of folklore in terms of tradition, we acknowledge the process by which individuals reshape the shared past to create a shared future. In speaking of identity, we recognize that individuals are inviolably themselves, alone in psychic continuity, yet linked to the others with whom they identify. If we speak of performance, we concentrate on the instants when individuals forge connections with others through artful enactment." [1, p. 9].

Furthermore, by quoting the opinion of Alan Dundes, Simon J. Bronner [2] sees folklore as a medium for the inheritance of a group's cultural values to its offspring and society. " $[\ldots]$ folklore is an essential way that cultural knowledge and wisdom is passed down. from generation to generation and from peer to peer." [2, p. 53] This opinion is also supported by Karen Kartomi Thomas [3] who says that oral tradition, "Keeps a people's culture alive across generations by performing episodes live from memory, episodes which express and reinstate people's values." [3, p. 5] So the extinction of the oral tradition means the loss of ancestral values which are an important element in culture. Therefore, the preservation of oral traditions, including folktales needs to be done to maintain the identity of a society.

The oral tradition of Manggarai consists of various forms, namely oral literature in the form of go'et (expressions), tombo nunduk (legend), tombo turuk (folktales), tombo bundu 
(proverbs), torok (traditional speech), and traditional songs [4] [5]. These forms of oral tradition are an essential part of the Manggarai community because they represent the community's life and show an "insider perspective" towards their own culture [6]. This article analyzes the understanding of Manggarai youth of tombo turuk (folktales) and its transmission methods from generation to generation. Changes in the cultural environment that scurry following the pace of modernity and information technology in Manggarai since the 1980s [7] have had a significant impact on understanding community members to their oral tradition.

The analysis of the two research problems above shows the continuity and form of Manggarai cultural values inheritance. Furthermore, alternatives and strategies of the Manggarai folktale transmission searched for a more appropriate and in line in facing the challenges of globalization.

\section{Literature Review}

The position of folktale as an essential part of an oral tradition can be seen in some research. Naz [8] sees folktale as "a source for compilation" of local history before written history. Boru [9] and Revika \& Hayati [10] discuss the function of folktale in two cultures, namely the people of Guji Oromo in Ethiopia and Minangkabau in West Sumatra, Indonesia. In the people of Guji Oromo and Minangkabau, there are similarities in the functions of folklore, namely as a tool to preserve cultural heritage, a medium of instruction to teach children philosophy and values of life, as entertainment, and direct people to live according to their social orders and morality. The difference is that there is a more explicit political function in the people of Guji Oromo, namely addressing political affairs that cannot be expressed directly.

Apart from having social, political, economic, and cultural functions, folklore also forms the cultural identity. Fatih Mehmet Berk [11] exemplifies the myths in Phrygia's civilization to shape their cultural identity from a historical point of view because, according to him, the memory of individual forms an identity of an individual so does a memory of a nation forms the identity of a nation. The same thing was said by Onusa Suwanpratest [12], folktale which contains cultural values from various nations in Asia, can show society's lifestyle. The similarity in the patterns of behavior of various nations in Asia can be seen in their folktale. In fact, in Gyem's [13] analysis, folktale is used as a symbol of the binary opposition between goodness and badness, a symbol of light instead of dark, and positivity as opposed to negativity.

Seeing the various functions and essential roles of folklore, its transmission from generation to generation is crucial. Moreover, the Manggarai folklore as part of the oral tradition faces various challenges in communication technology era. John H. McDowell [14] suggests looking at the transmission of folklore through two theories. First, theories view folklore transmission as a superorganic, mechanical process, and the second theories emphasize its serendipitous and emergent character. In the first theory, folklore transmission becomes an impersonal process to be inferred and reconstructed based on exclusively philological evidence $[14$, p. 50$]$.

In contrast, in the second theory, folklore transmission residing in the performancecentered approach is one concerned with "the interplay between communicative resources, individual competence, and the goals of the participants, within the context of particular situations." [14, p. 51]. 
The analysis of the two research problems above shows the continuity and form of Manggarai cultural values inheritance. Furthermore, alternatives and strategies of the Manggarai folktale transmission searched for a more appropriate and in line in facing the challenges of globalization.

\section{Method}

This research is a qualitative research, this research is a qualitative research using survey and interview methods for data collection. [15]. The survey was conducted online using Google Forms on 146 respondents from the Indonesian Language and Literature Education Study Program at Universitas Katolik Indonesia Santu Paulus Ruteng, aged between 19-28 years and came from five classes with three different batch. The reasons for choosing this group as respondents were first, as students of the Indonesian language and literature education study program, they were assumed to be a group that knew, appreciated, and understood the function and role of oral and local literature. Second, as an educated group, they have more access to understand folktale or oral tradition. Third, all respondents are Manggarai people, who come from West Manggarai Regency, Manggarai Regency, and East Manggarai Regency, so it is assumed that they know the folktale originating from their area.

At this stage, five questions were asked, consisting of two questions about the respondent's understanding to the Manggarai folklore and three questions related to the transmission of the Manggarai folktale from generation to generation. The two topics were used to measure the respondents' knowledge of the Manggarai folktale and the form of transmission. To confirm and deepen their answers that have been done in the questionnaire, in-depth interviews were conducted with fifteen students who were considered to represent the population. Based on Arikunto's [16] opinion, in a population of more than 100 people, 10 percent can be taken as the sample. Therefore, in the interview stage, ten percent of the total was taken, although this determination also contained qualitative considerations with the purposefully select method, deliberately choosing the interviewees [15], namely three people from each class who became the population.

The data analysis strategy undertaken is to analyze the respondents' answers obtained by using an online format. The data then classified according to the predetermined research topics. After the quantitative data was concluded, a comparison was made to the qualitative data, carried out using in-depth interviews with the selected respondents. The next step is data interpretation. In interpreting these data's, it tends to use qualitative methods because the quantitative data obtained is then deepened with interviews to determine the causes for the emergence of answers as contained in quantitative data.

\section{Result and Discussion}

The questions in the questionnaire covered two topics, namely the respondents' recognition to the Manggarai folktales and how the folktales were transmitted to them. The results obtained based on these two issues can be seen in the explanation below. The first question is whether they are familiar with the Manggarai folklore. Of the 146 respondents, 95.2 percent or 139 people stated that they knew it, while 4.8 percent or seven people did not know the Manggarai folktales. Based on this question, respondents who stated that they did 
not know the Manggarai folktale did not answer the following question. Based on the results of these answers, only 139 people continued to answer questions containing recognition and transmissions of Manggarai folktales.

The next question related to the understanding of Manggarai folktales is how many Manggarai folktales they know. Of the 139 respondents, 60 people, or 43.16 percent, said that they knew one story, 33 people or 23.74 percent knew two stories, and 7.91 percent or 11 people knew three stories. The rest, namely 35 people or 25.17 percent, knew more than three stories. The further question relates to the second issue, namely the transmission of the Manggarai folktales to the younger generation. In this section, the first question that must be answered is how they know the Manggarai folktale. The answers from 82 people, or 58.99 percent, indicated that their grandparents were the ones who introduced them to folk tales. Parents, fathers or mothers, are the other parties who tell the folktale to 38 people or 27.3 percent. Meanwhile, the media in the form of books introduced the Manggarai folklore to 11 people or 7.91 percent. The rest, namely eight people or 5.75 percent, know the folktale through various electronic media and the internet.

The second question regarding the transmission of this folktale concerns the language used in the inheritance of the Manggarai folktale. This question deals with the ease of inheritance and originality of the story. Based on respondents' answers, as many as 71 people or 51.07 percent received stories in Manggarai language, 17 people or 12.2 percent knew the stories in Indonesian, 50 people or 35.97 percent received stories from Manggarai tales using a mixture of Indonesian and Manggarai language, and only one person or 0.71 percent knew the folklore in English. The third question contains the level of education of the respondents when they know the Manggarai folktale. Based on this question, it is known that 92 people or 66.18 percent knew Manggarai folktale since elementary school, while 30 people or 21.58 percent only knew it at the junior high school level and 13 people or 9.35 percent in senior high school. Only four people, or 2.87 percent, knew about the folklore in higher education.

Based on the respondents' answers using a questionnaire, it is known that most respondents know the Manggarai folklore. Their level of understanding varies from 1 story to more than three stories. Most of the folktale transmission use the oral method, even though books and the internet have become alternative media. Meanwhile, their introduction to Manggarai folktale is mainly in the Manggarai language and obtained in elementary schools. These quantitative results then deepened using open interviews. This interview is based on questions on inheriting the Manggarai folktales from various sources or media, the causes, and when the folklore inheritance occurs.

Based on the research statement, there are two things discussed in this section: the recognition of the Manggarai folktales, including whether someone knows folktales and how much they know. This question shows that most Manggarai people or those who live in Manggarai, with various levels, are familiar with it. Even so, 4.8 percent of respondents admitted that they did not know the Manggarai folktales. Based on the interview results, it is known that people who do not know the Manggarai folklore are because their parents never transmitted it, the limited knowledge of the parents is also the reason why there is no transfer of knowledge to their children. Another reason is that their parents are migrants, so they stay outside Manggarai until they reach adulthood. In this group, Manggarai cultural transmission is limited so that it is not familiar with the stories of its ancestors.

The survey results and interviews show that the transmission of Manggarai folklore to the younger generation between the ages of 18-28 years is still happening. Even so, several things are of concern in transmitting Manggarai culture; among others, there is a possibility that this folklore cannot be passed on to the next generation if more and more parents do not know the 
folklore. In addition, the rapid migration out of Manggarai [17] [18] [19] can cause the inheritance of Manggarai culture, especially its folklore, to not last.

Respondents' level of recognition of the Manggarai folktales varied. The data shows that most respondents know less than three stories, whereas at the moment, there are eighty-six titles of Manggarai folk tales documented by various parties [20] [21] [22] through several books. In addition, there are various versions of the story by region that the researchers have not transliterated. The comparison between the number of folktales and the respondents' recognition shows that, first, even though they are familiar with Manggarai folktales, their recognition is minimal.

Based on the interview, it can be seen that respondents who only know one or two stories are due to factors; first, their families do not know much about Manggarai folklore, so they only tell the folktales they know. Second, children do not feel interested in folktales because they are considered not by reality, so that it is difficult for them to understand them. Third, the transmission of folklore using the Manggarai language by grandparents is challenging because most parents communicate with their children in Indonesian rather than local languages. Fourth, families never tell folktales so that their children find out about them from other sources. This determinant causes the younger generation to be unable to properly access folklore. Meanwhile, respondents who knew more than three stories said they did not rely on the transmission of folklore from their families. Folklore books in school libraries or muatan lokal (local content subject) books are the source of their introduction to folklore. In addition, several Manggarai culture's website also contains some Manggarai folktales.

Based on the data above, it can be seen that the level of recognition of the younger generation of Manggarai folktales correlates with the sources of telling the folktales. A person who has greater access to and interest in it has a better familiarity with the folktales of his or her area than other people who are not interested or do not have access to the story's transmission through family or other media. Therefore, the younger generation's less interest in their folktale due to modernity or an increasingly rare inheritance from previous generations can make it more difficult for folktales recognized by the next generation. One respondent also said that children are more interested in using gadgets than listening to stories from their parents. This phenomenon is both a challenge and an opportunity because information technology tools can make the inheritance of cultural values more difficult, or it becomes a means of preserving them by changing the format of transmission to the younger generation.

The second problem that this article tries to answer is the inheritance of the Manggarai folktales between generations. Three things become indicators: who or what, when, and how the folklore transmit from generation to generation. In the first part, it is known that the majority of respondents, namely 86.29 percent, know folklore through grandparents and parents. Several things caused this, first the limitations of information technology in the 2000s. In the past decade, Manggarai residents still relied on conventional media such as radio and television to obtain information and connect with outside the region. Limitations of the media connect with the outside world, such as television and radio, are coupled with the lack of electricity connections and mountainous geographical conditions. A satellite dish is needed to access television channels, while a government-run radio station was the only radio accessed in rural areas.

This condition causes custom or social events to be the only channel for people to communicate intensely with each other. Social events celebrated by all community members not only as part of their identity or social relations but also as entertainment. Apart from formal events, other activities carried out to entertain family members are singing traditional songs, commonly called nenggo [4]. Through these songs, various aspects of life are sung, 
including pieces of advice that contain the cultural values of the Manggarai people. Apart from nenggo, another entertainment usually done at night is storytelling by grandparents or parents to their young children.

In the context of folklore transmission, according to C.W. von Sydow [14] "Only a very small number of active bearers of tradition equipped with a good memory, vivid imagination, and narrative powers do transmit the tales. It is only they who tell them. Among their audience, it is only a small percentage still do so. Most of those who have heard a tale told and can remember it remains passive carriers of tradition, whose importance for the continued life of the tale consists mainly in their interest in hearing it told again." [14, p. 50].

The remaining 13.71 percent know folktales from other sources in books or blogs containing Manggarai culture. It is further explained that the introduction of Manggarai folklore is not always based on the desire of parents or children to get to know its culture, but due to the obligation of the school in the form of assigning appreciation of folktales or material in local content subjects. It may explain the limited recognition of most respondents to local stories. The chances of transmitting folktales to people aged 19-28 years are more significant because of these factors, but technological advances can pose challenges to inheritance to later generations. Further research is needed to see the process of transmitting these folktales to younger age groups to know the continuity of this inheritance.

Data on the inheritance of folktales to respondents corresponded to the level of education when they heard the stories being told. More than half of the respondents answered that they were familiar with folklore at the elementary school level. It can be interpreted that they heard the story through their family or loved ones. The second source is lessons in schools that have local content curricula at the elementary school level. Third, at the age of children, they are more attached to older people than teenagers, so that the chances of transmitting folklore to them are more significant than at other educational levels.

The results of the interviews also showed that the introduction of folklore at the secondary school level was because they did not get storytelling when they were young and only started reading it in middle school when the teacher gave a literary appreciation assignment, likewise for respondents who know about the Manggarai folklore at the tertiary level. They know the story because of their college assignments rather than a personal desire to know the culture. However, the interest in Manggarai folktale by respondents with a higher level is driven by an awareness of preserving values and identity as Manggarai people, so they are included in the group of respondents who know more than three stories.

The last part of the method of transmitting the Manggarai folktales to the younger generation is the use of language to inherit it. The data shows that half of the respondents answered that they knew folk tales in local languages. More than a quarter knew it by a mixture of Manggarai and Indonesian, while the rest knew the story in Indonesian and one person in English. This data correlates with previous data regarding the respondents' level of education when they get to know folktales and their storytellers.

At the primary school level, most respondents are still accustomed to speaking Manggarai. It is influenced by the origins of respondents who mostly come from rural areas where regional languages are used daily. It is supported by the results of interviews, which state that at the primary school level in the villages, the teaching and learning process does not fully use Indonesian. Due to homogeneous rural communities, the limited education level of the majority of the population and a lack of information affects Indonesian language skills, making regional languages the primary communication tool.

Another reason has to do with the data on the media of passing stories to the respondents. Most of the respondents know folktales based on stories from grandparents and parents. It 
explains why most know the story in the Manggarai language version. In families in rural Manggarai, regional languages are the primary means of communication, including communication between parents and children or social interactions. When continuing their education in secondary schools, both junior and senior high schools, some students go to school in district capitals [18].

In cities as centers of education and government, so does more pluralistic society, Indonesian is more commonly used. In addition to bridging communication between residents and migrants, Manggarai society itself has different accents between regions, so Indonesian is a solution to these differences. In this condition, the Indonesian version of the Manggarai folktales was known by the respondents. At this educational level, appreciation of regional literature is also carried out in language learning to get folktales material through books and internet sites.

The exciting thing is that one of the 146 respondents knows the folktales of Manggarai using a foreign language, in this case, English. At the high school level, understanding Manggaraian folktales occurred when foreign language learning used folk tales from their regions. Research conducted by Nhung [23] shows that folklore helps teach foreign languages because it is rich in authentic vocabulary, provides information about the cultural background of a group, and can be used in various learning activities. Thirty Manggarai folk tales have been recorded and translated into English by Su, Fatmawati, \& Darong [22] with the title Manggaraian Grannies' Tales: Tombo Turuk Disé Empo. This book can be a reference for teaching English with local content.

Based on the analysis above, it can be seen that Manggarai cultural inheritance through folklore for the 19-28-year-old population is still going well, but the continuation of inheritance to the younger age group is not yet known. This condition can be a challenge in the future if the adult group does not have the desire to pass on the stories to their children for various reasons.

Folklore does not only function as the inheritance of a group's values, norms, and philosophy but also becomes a cultural identity. Block said, "[...] language and cultural identities denote the membership of a shared language and culture regardless of nationality and ethnicity that can further shape people's behavior and attitude" [24, p. 1]. The absence of folklore inheritance can erode the Manggarai language from its speakers. The loss of a language means losing the cultural roots and values of a cultural group. It needs to be watched out because in the era of globalization with high human mobility, language preservation can be a big problem for an ethnic group.

\section{Result and Discussion}

The process of transmitting Manggarai folklore to the younger generation between 19-28 years old is still going well. Most of them are familiar with folk tales told by parents, grandparents, or other media such as books and blogs on the internet. The recognition is insignificant when seen by the number of their understanding of the stories in the folk tales. Most of the respondents only knew one folktale among dozens of titles that had been transliterated and documented by researchers in Manggarai.

Understanding the Manggarai folklore in the younger generation is also related to the preservation of the local language as the identity of its people. Most of these folklore transmission processes use the Manggarai language, but the number of folk tales known in 
mixed Indonesian and Manggarai languages and Indonesian languages is significant. If transmitting the Manggarai folklore is not carried out in the regional language, there is a possibility that the Manggarai language users will decrease and not actively use it anymore. It can lead to the extinction of regional languages in the Manggarai region.

Efforts to preserve the Manggarai folklore can be carried out; first, the process of transmitting folklore conventionally must be accompanied by other media that are by the times, such as films, instructional videos, or comic books. Second, the inventory of Manggarai folk tales must be carried out continuously to document the stories. The documentation results were recorded and disseminated to students so that the interruption of transmission from parents due to their lack of understanding of Manggarai folk tales can be bridged with written sources. Language has an essential role in maintaining identity; therefore, it is necessary to make bilingual or multilingual books containing Manggarai folk tales. Apart from being used to transmit folklore and the inheritance of Manggarai cultural values, these books also serve to introduce and preserve the Manggarai language to the next generation.

\section{References}

[1] W. A. Wilson, "The Deeper Necessity: Folklore and the Humanities," in Marrow of Human Experience: Essays on Folklore, Logan, Utah State University Press, 2006, pp. 9-22.

[2] S. J. Bronner, "Folklore as a Mirror of Culture," in Meaning of Folklore: The Analytical Essays of Alan Dundes, Logan, Utah State University Press, 2007, pp. 1-66.

[3] K. K. Thomas, "Cultural Survival, Continuance and the Oral Tradition: Mendu Theatre of the Riau Islands Province, Indonesia," IJCAS: Vol. 2, Number 2, pp. 1-6, 2015.

[4] P. Janggur, Butir-butir Adat Manggarai 1, Ruteng: Percetakan Artha Gracia, 2008.

[5] K. T. Deki, Tradisi Lisan Orang Manggarai., Jakarta: Parrhesia Institute Jakarta, 2011.

[6] M. Regus, "Memangkas Prasangka, Membangun Kedaulatan Budaya: Catatan Pengantar," dalam Tradisi Lisan Orang Manggarai Membidik Persaudaraan dalam Bingkai Sastra, Jakarta, Parreshia Institute Jakarta, 2011, pp. 21-28.

[7] R. P. Webb, "The Children of Mori Kereng: Education and Development Strategies in Manggarai, Flores," Phillipines Quarterly of Culture \& Society 22, pp. 141-158, 1994.

[8] H. Naz, "Significance of folklore as a source of history and culture: A critical appraisal with special reference to the folklore of Sindh (Pakistan)," dalam 23rd International Conference of Historians of Asia 2014 (IAHA2014), Kedah, 2014.

[9] G. Boru, "An Analysis of Guji Oromo Folktales: Function in Focus," International Journal of Humanities \& Social Science Studies (IJHSSS) Volume-III, Issue-IV, pp. 224-242, 2017.

[10] Revika dan Y. Hayati, "Categories, Structure, And Function of Folklore in Lima Puluh District Communities,” RETORIKA: Jurnal Bahasa, Sastra, dan Pengajarannya, Volume 13, No. 1, p. 137145 DOI: 10.26858/retorika.v13i1.11303, 2020.

[11] F. M. Berk, "The Role of Mythology as a Cultural Identity and a Cultural Heritage: the Case of Phrygian Mythology," Procedia Social and Behavioral Sciences 225, pp. 67-73 DOI: 10.1016/j.sbspro.2016.06.009, 2016.

[12] O. Suwanpratest, "An Analysis of the Prominent Cultural Values of Asian People through Similar Folktales," International Journal of Social Science and Humanity, Vol. 6, No. 11, pp. 836-839 doi:10.18178/ijssh.2016.6.11.759, 2016.

[13] K. J. Gyem, "A Korean Folktale, Kongjee-Patjee: An Analysis of The Concept of Binary Opposition," Humaniora Vol 23 No. 2, pp. 166-174, 2011.

[14] J. H. McDowell, "The Transmission of Children's Folklore," in Children's Folklore: A Source Book, Logan, Utah State University Press, 1999, pp. 49-62.

[15] J. W. Creswell, Research Design: Pendekatan Metode Kualitatif, Kuantitatif, dan Campuran, Yogyakarta: Pustaka Pelajar, 2016.

[16] S. Arikunto, Prosedur penelitian : Suatu Pendekatan Praktik, Jakarta: Rineka Cipta, 2010. 
[17] A. P. Yuliantari, "Migration and Manggaraian's Cultural Identity as Represented in Manggaraian Rap Songs," International Journal of Humanity Studies, pp. 164-177 DOI: https://doi.org/10.24071/ijhs.v3i2.2195, 2020a.

[18] A. P. Yuliantari, "Technoscapes and mediascapes influence on village and city relations in Manggarai, East Nusa Tenggara," Simulacra (3)1, pp. 1-13 DOI: https://doi.org/10.21107/sml.v3i1.7112, 2020b.

[19] A. P. Yuliantari, Y. S. Lon dan F. Widyawati, "Manggaraian People's Perspective on Migration: A Study of Popular Manggaraian Songs' Lyrics," Mozaik Humaniora (20)1, pp. 1-11 DOI 10.20473/mozaik.v20i1.15681, 2020.

[20] J. Verheijen, Dongeng-dongeng Manggarai Jilid 1, Maumere: Penerbit Ledalero, 2006.

[21] K. Barung, Pembelajaran Cerita Lokal Manggarai Timur, Ruteng: CV Graffiko, 2010.

[22] Y. R. Su, Fatmawati dan H. C. Darong, Manggaraian Grannies' Tales: Tombo Turuk Dise Empo, Ruteng: STKIP St. Paulus Ruteng, 2016.

[23] P. T. H. Nhung, "Folktales as a Valuable Rich Cultural and Linguistic Resource to Teach a Foreign Language to Young Learners.," International Journal of Education, Culture and Society. Vol. 1, No. 1, pp. 23-28. DOI: 10.11648/j.ijecs.20160101.15, 2016.

[24] F.-W. Kung, "The renegotiation and redefinition of Taiwanese students' language and cultural identities in Mainland China," International Journal of Bilingualism, pp. 1-15 DOI: 10.1080/13670050.2018.1461191, 2018. 